\title{
A high performance non-noble metal electrocatalyst for the oxygen reduction reaction derived from a metal organic framework
}

\author{
Yangzhi Bai a,b, Baolian Yi a , Jia Li c ${ }^{c}$, Shangfeng Jiang a , Hongjie Zhang a, Zhigang Shao a,*, \\ Yujiang Song c,\# \\ a Dalian National Laboratory for Clean Energy, Dalian Institute of Chemical Physics, Chinese Academy of Sciences, Dalian 116023, Liaoning, China \\ b University of Chinese Academy of Sciences, Beijing 100049, China \\ ' State Key Laboratory of Fine Chemicals, School of Chemical Engineering, Dalian University of Technology, Dalian 116024, Liaoning, China
}

\section{A R T I C L E I N F O}

Article history:

Received 15 March 2016

Accepted 12 April 2016

Published 5 July 2016

\section{Keywords:}

Fuel cell

Oxygen reduction reaction

Non-precious metal catalyst

Metal organic framework

Alkaline condition

\begin{abstract}
A B S T R A C T
The development of a non-precious metal electrocatalyst (NPME) with a performance superior to commercial Pt/C for the oxygen reduction reaction (ORR) is important for the commercialization of fuel cells. We report the synthesis of a NPME by heat-treating Co-based metal organic frameworks (ZIF-67) with a small average size of $44 \mathrm{~nm}$. The electrocatalyst pyrolyzed at $600{ }^{\circ} \mathrm{C}$ showed the best performance and the performance was enhanced when it was supported on BP 2000. The resulting electrocatalyst was composed of $10 \mathrm{~nm}$ Co nanoparticles coated by 3-12 layers of $\mathrm{N}$ doped graphite layers which as a whole was embedded in a carbon matrix. The ORR performance of the electrocatalyst was tested by rotating disk electrode tests in $\mathrm{O}_{2}$-saturated $0.1 \mathrm{~mol} / \mathrm{L} \mathrm{KOH}$ under ambient conditions. The electrocatalyst $\left(1.0 \mathrm{mg} / \mathrm{cm}^{2}\right)$ showed an onset potential of $1.017 \mathrm{~V}$ (vs. RHE) and a half-wave potential of $0.857 \mathrm{~V}$ (vs. RHE), which showed it was as good as the commercial Pt/C $\left(20 \mu \mathrm{g}_{\mathrm{pt}} / \mathrm{cm}^{2}\right)$. Furthermore, the electrocatalyst possessed much better stability and resistance to methanol crossover than Pt/C.
\end{abstract}

(C) 2016, Dalian Institute of Chemical Physics, Chinese Academy of Sciences. Published by Elsevier B.V. All rights reserved.

\section{Introduction}

For its high energy conversion efficiency, high power density, low operating temperature, long life span, and low or zero emission of pollutants, fuel cell technology has attracted attention [1,2]. The commercial Pt/C catalyst remains the most popular electrocatalyst for the oxygen reduction reaction (ORR) in fuel cells [3-5]. However, the limited reserve, relatively low stability, CO poisoning and deactivation by crossover methanol have prevented Pt-based electrocatalysts from widespread commercialization in fuel cells [6,7]. Therefore, the develop- ment of a high performance non-precious metal electrocatalyst (NPME) for the replacement of Pt-based electrocatalysts would be an ideal solution [8].

In recent years, metal organic framework (MOF) as a precursor has been employed for the preparation of NPMEs. MOFs are crystalline porous materials with a periodic network formed by the self-assembly of transition metal ions and organic ligands [9]. Due to their tunable pores, ultra-low density, and high specific surface area [7], MOFs have drawn tremendous attention as a new class of porous materials with potential applications in hydrogen storage [10,11], $\mathrm{CO}_{2}$ capture [12],

\footnotetext{
* Corresponding author. Tel: +86-411-84379153; Fax: +86-411-84379153; E-mail: zhgshao@dicp.ac.cn

\# Corresponding author. E-mail: yjsong@dlut.edu.cn

This work was supported by the National Basic Research Program of China (973 Program, 2015CB932304) and the National Natural Science Foundation of China (21436003).

DOI: 10.1016/S1872-2067(15)61104-4 | http://www.sciencedirect.com/science/journal/18722067 | Chin. J. Catal., Vol. 37, No. 7, July 2016
} 
chemical separation [13,14], catalysis [15], biomedical imaging $[16,17]$, chemical sensors [18] and magnetic applications [19]. Compared to the commonly used NPME precursors comprising a carbon support, nitrogen-containing ligands and transition metal salts, MOF possesses a periodic 3D-network structure that can provide not only abundant desired moieties but also a uniform and regular porous structure [20]. Hence, many MOFs have already been selected for the preparation of ORR electrocatalysts. Li et al. [21] synthesized a NPME with high electrochemical performance in both acidic and alkaline condition by heat-treating a mixture of a novel Co-containing MOF material with giant polyhedral cages, dicyandiamide (DCDA) and iron species. Zhang et al. [22] reported an alkaline NPME produced by the pyrolysis of triphenylphosphine and highly porous doped carbon nanofibers derived from ZIF-8 nanofibers.

Imidazole zeolite frameworks (ZIFs) are an important class of MOFs. Their thermal and chemical stability, high specific surface area, high nitrogen content, and uniform distribution of transition metals and nitrogen-containing ligands make ZIFs unique NPME precursors [1], in particular, ZIF-67 has a sodalite topology in which every cobalt cation is bridged with four nitrogen atoms of 2-methylimidazolate anions. Wang et al. [23] have made electrocatalysts with ZIF-67, ZIF-8 and Co2(bdc)2(dabco) in both acidic and alkaline solution. Hu et al. [24] and Chen et al. [25] have made S-doped electrocatalysts for ORR and both oxygen reduction and evolution reactions with ZIF-67. Aijaz et al. [26] have made bifunctional electrocatalysts for oxygen electrodes comprising $\mathrm{Co}_{0} \mathrm{Co}_{3} \mathrm{O}_{4}$ nanoparticles embedded in CNT-grafted N-doped carbon-polyhedra obtained by the pyrolysis of ZIF-67 in a reductive $\mathrm{H}_{2}$ atmosphere and subsequent controlled oxidative calcinations. Xia et al. [20] have used ZIF-67 with different particle sizes as precursors to synthesize ORR electrocatalysts in acidic solution. From the results, we can see that the electrochemical performance of NPME is closely related to the size of the ZIF-67 precursors. The smallest ZIF-67 particles (300 nm) showed the best electrochemical performance. This may be because the smaller ZIF-67 supplied more active and easily accessible sites and thus promoted faster mass and electron transfer. In this study, we report the synthesis of the smaller ZIF-67 (about $44 \mathrm{~nm}$ ) and subsequent pyrolysis with and without a BP 2000 carbon support. The resultant NPME demonstrated high ORR performance in terms of the half-wave potential and is more stable in alkaline medium than a commercial $\mathrm{Pt} / \mathrm{C}$ catalyst.

\section{Experimental}

\subsection{Preparation of ZIF-67 and ZIF-67/C}

$\mathrm{Co}\left(\mathrm{NO}_{3}\right)_{2} \cdot 6 \mathrm{H}_{2} \mathrm{O}(>99 \%)$ was purchased from Xilong Chemical Reagent Co. (Guangdong, China) and 2-methylimidazole was purchased from Aladdin Chemical Reagent Co. (Shanghai, China). The chemicals were used as received. Milli-Q UV-plus water $(18.2 \mathrm{M} \Omega \cdot \mathrm{cm}$ ) from a Millipore water system (Synergy® UV, France) was used in the experiments.

In a typical synthesis, $921 \mathrm{mg} \mathrm{Co}\left(\mathrm{NO}_{3}\right)_{2} \cdot 6 \mathrm{H}_{2} \mathrm{O}$ was placed into a $250 \mathrm{~mL}$ round bottom flask, followed by the addition of
$125 \mathrm{~mL}$ of anhydrous methanol. After mild sonication in a water bath cleaner for $5 \mathrm{~min}, \mathrm{Co}\left(\mathrm{NO}_{3}\right)_{2} \cdot 6 \mathrm{H}_{2} \mathrm{O}$ was homogeneous dissolved in methanol. Next, $2.079 \mathrm{~g}$ 2-methylimidazole was added to the mixture. Another 5 min of mild sonication was applied to ensure the complete dissolution of 2-methylimidazole. The mixture was incubated at $25{ }^{\circ} \mathrm{C}$ with stirring for $22 \mathrm{~h}$. Finally, ZIF-67 was obtained as a purple precipitate. The product was collected by centrifugation at 8000 $\mathrm{r} / \mathrm{min}$ for $8 \mathrm{~min}$, followed by drying under vacuum at $80^{\circ} \mathrm{C}$ for $4 \mathrm{~h}$.

The synthesis of ZIF-67/C was identical to that described above for ZIF-67, except that 75 mg BP 2000 was added after the addition of 2-methylimidazole.

\subsection{Electrocatalyst synthesis}

The ZIF-67 was pyrolyzed under an argon atmosphere for 2 $\mathrm{h}$ at different temperatures ranging from 500 to $900{ }^{\circ} \mathrm{C}$ with a heating ramp of $5{ }^{\circ} \mathrm{C} / \mathrm{min}$ and cooled down naturally to ambient temperature. The eletrocatalysts were marked as ZIF-67-Tc, where Tc stands for the thermal treatment temperature. The heat treatment procedure for ZIF-67/C was the same as that of ZIF-67 and the corresponding electrocatalyst was marked as ZIF-67/C-600. Finally, all the electrocatalysts were ground to a fine powder.

\subsection{Physical characterization}

Transmission electron microscopy (TEM) was conducted on JEM-2000EX operated at $120 \mathrm{kV}$ and JEM-2100 operating at $200 \mathrm{kV}$. Powder X-ray diffraction (XRD) patterns were collected on a D/MAX2500VB2/PC with a $2 \theta$ range of $5^{\circ}-90^{\circ}$ and a scan speed of $5 \%$ min at ambient temperature. X-ray photoelectron spectroscopy (XPS) was carried out on a Thermo Scientific ESCA Lab250 Xi spectrometer. The metal content of the electrocatalysts was determined by a PerkinELmer 7300DV inductively coupled plasma atomic emission spectrometry (ICP-OES).

Nitrogen sorption measurements at $-196{ }^{\circ} \mathrm{C}$ were carried out using a Quantachrome Autosorb-IQ gas adsorption analyzer. The samples were degassed at $90^{\circ} \mathrm{C}$ for $2 \mathrm{~h}$ and $200{ }^{\circ} \mathrm{C}$ for 5 $\mathrm{h}$ under vacuum first. The resulting BET surface area was calculated from the adsorption branch. The pore size distribution was fitted using the Quenched Solid Density Functional Theory (QSDFT) method.

\subsection{Electrochemical measurements}

A CHI electrochemical station (Model 760D) and a conventional three-electrode electrochemical cell were used for electrochemical measurements at room temperature. A platinum plate and mercuric oxide electrode $(\mathrm{Hg} / \mathrm{HgO})$ were used as the counter and reference electrode, respectively. The electrolyte was $0.1 \mathrm{~mol} / \mathrm{L} \mathrm{KOH}$ aqueous solution. For the preparation of the catalyst ink, some Nafion solution ( $5 \mathrm{wt} \%$ ), ultra-pure water and ethanol ( $\left.V_{\text {Nafion}}: V_{\text {water: }} V_{\text {ethanol }}=0.1: 1: 9\right)$ were mixed with an electrocatalyst and sonicated in a water bath for $10 \mathrm{~min}$ to 
get the catalyst ink $(2 \mathrm{mg} / \mathrm{mL})$. An amount of catalyst ink was loaded on the glassy carbon rotating disk electrode (RDE, diameter $5 \mathrm{~mm}$, Pine Instruments, USA) for the electrochemical measurements.

Cyclic voltammetry (CV) experiments were performed in $\mathrm{O}_{2}$ or $\mathrm{N}_{2}$ purged aqueous $\mathrm{KOH}(0.1 \mathrm{~mol} / \mathrm{L})$ with the potential ranging from 0.097 to $1.097 \mathrm{~V}$. The scan rate was $100 \mathrm{mV} / \mathrm{s}$. Linear sweep voltammograms (LSVs) were performed on the catalyst-coated RDE in $\mathrm{O}_{2}$ saturated $\mathrm{KOH}(0.1 \mathrm{~mol} / \mathrm{L})$ between 0.097 and $1.097 \mathrm{~V}$ at $1600 \mathrm{r} / \mathrm{min}$ and a scan rate of $5 \mathrm{mV} / \mathrm{s}$.

In the rotating ring-disk electrode tests (RRDE, PINE AFE7R9GCPT), the ring potential was set at $1.197 \mathrm{~V}$ versus RHE. The number of electron transferred $(n)$ during the ORR and the $\mathrm{H}_{2} \mathrm{O}_{2}$ yield $\left(\% \mathrm{H}_{2} \mathrm{O}_{2}\right)$ were calculated using the following equations:

$$
\begin{aligned}
& \% \mathrm{H}_{2} \mathrm{O}_{2}=200 I_{\mathrm{r}} /\left(N\left|I_{\mathrm{d}}\right|+I_{\mathrm{r}}\right) \\
& n=4-2 \times \% \mathrm{H}_{2} \mathrm{O}_{2} / 100
\end{aligned}
$$

where $N$ is the collection efficiency (0.37), $I_{\mathrm{r}}$ and $I_{\mathrm{d}}$ are the ring current and disk current, respectively.

Koutecky-Levich plots were obtained on the basis of the RDE tests at different rotating rates. The electron transfer number during the ORR process was determined from the slopes of Koutecky-Levich plots by the following equation:

$$
j \lim =0.62 n F A D_{0}^{2 / 3} v^{-1 / 6} C_{0} \omega^{1 / 2}
$$

where $j_{\text {lim }}$ is the limiting current density, $n$ is the number of electrons transferred per oxygen molecule, $F(96485 \mathrm{C} / \mathrm{mol})$ is the Faraday constant, $D\left(1.9 \times 10^{-5} \mathrm{~cm}^{2} / \mathrm{s}\right)$ is the diffusion coefficient of $\mathrm{O}_{2}$ in $0.1 \mathrm{~mol} / \mathrm{L} \mathrm{KOH}$ and $C_{0}\left(1.2 \times 10^{-6} \mathrm{~mol} / \mathrm{L}\right)$ is the concentration of $\mathrm{O}_{2}$ in the electrolyte, $v$ is the kinetic viscosity of the solution $\left(0.01 \mathrm{~cm}^{2} / \mathrm{s}\right)$, and $\omega$ is the electrode rotation rate $(\mathrm{rad} / \mathrm{s})$.

For the accelerated stability test (AST), the electrodes were cycled between 0.497 and $1.097 \mathrm{~V}$ for a total number of 2000 cycles in $\mathrm{O}_{2}$ saturated $\mathrm{KOH}(0.1 \mathrm{~mol} / \mathrm{L})$ with a scan rate of 100 $\mathrm{mV} / \mathrm{s}$. Meanwhile, the CV curves and ORR polarization curves were collected in aqueous $\mathrm{KOH}$ solution at specific cycles to track the degradation of ZIF-67/C-600 and commercial Pt/C.

\section{Results and discussion}

The morphologies of the ZIF-67 precursor, ZIF-67-600, and ZIF-67/C-600 were analyzed by TEM. In this MOF, each cobalt cation is bridged with four nitrogen atoms from the 2-methylimidazolate anions into tetrahedral frameworks and further assembled into a sodalite (SOD) topology. An average particle size of $44 \mathrm{~nm}$ ZIF-67 precursor was synthesized at room temperature in methanol solvent as shown in Fig. 1(a).

Compared with ZIF-67, both ZIF-67-600 and ZIF-67/C-600 samples did not preserve their original shape (Fig. 1(b) and (c)). Instead, they were composed of graphite layer-wrapped Co nanoparticles embedded in the carbon matrix. The Co nanoparticles exhibited (111) lattice fringes with a typical spacing of $0.204 \mathrm{~nm}$ (Fig. 1(d), inset). The Co nanoparticles were formed during the heat-treatment process of ZIF-67 at a high temperature. Multi-layered graphite was observed to envelope the Co nanoparticles as shown in Fig. 1(d). The formation of the graphite layer around Co likely resulted from the catalytic ef-

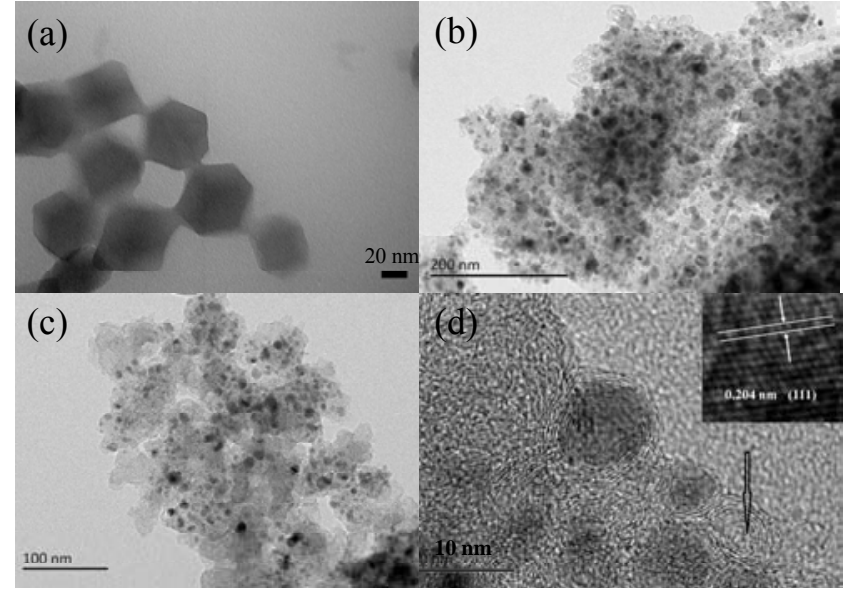

Fig. 1. TEM images of ZIF-67 precursor (a), ZIF-67-600 (b) and ZIF-67/C-600 (c, d).

fect of Co for carbonization during the pyrolysis process. The graphite layer is beneficial for the stabilization of the Co nanoparticles in the carbon matrix.

The ZIF-67, ZIF-67-Tc and ZIF-67/C-600 structures were characterized by XRD. It showed that the synthesized precursor was pure ZIF-67 crystal without any detectable byproducts. The heat-treated products were composed of the pure metallic phase of face-centered cubic Co as shown in Fig. 2(a).

Based on the ICP-OES result, ZIF-67/C-600 contained up to $23 \mathrm{wt} \%$ Co. Indeed, Co has long been recognized to promote the four-electron ORR process in alkaline solution [27].

Nitrogen is viewed as a n-type carbon dopant that can facilitate the ORR [28]. Thus the nitrogen content and species are of great importance for the electrochemical performance of NPME. In this study, ZIF-67-600 has a relatively large nitrogen content (5.8 at\%, Table 1) [20], which is beneficial for the ORR. As shown in Fig. 2(b) and (c), the spectra can be decomposed into four peaks, namely pyridinic-N (398.8 eV), pyrrolic- $\mathrm{N}$ (400.4 eV), graphitic-N (401.3 eV), and oxidized-N (403.8 eV) [29]. From Table 1, we can see that pyridinic-N was the dominant species with smaller amounts of pyrrolic-N, graphitic- $\mathrm{N}$, and oxidized-N for both electrocatalysts. The amount of pyrrolic-N slightly increased for ZIF-67/C-600. In particular, pyridinic- $\mathrm{N}$ has been proposed as the active site to promote the four-electron process in the ORR which reduces the adsorption energy of $\mathrm{O}_{2}[30,31]$, so it is good for the ORR activity.

The surface area of the electrocatalyst also affects its electrochemical performance. Fig. 2(d) shows the $\mathrm{N}_{2}$ adsorption-desorption isotherms of ZIF-67, ZIF-67-600, and ZIF-67/C-600. ZIF-67 showed a typical Type I isotherm, indicating its microporous nature with a BET surface area of $A_{\text {BET }}$ $1146 \mathrm{~m}^{2} / \mathrm{g}$. After heat-treatment at $600{ }^{\circ} \mathrm{C}$, the isotherms of ZIF-67-600 and ZIF-67/C-600 also showed the presence of pores. The slight hysteresis loop and vertical tail of ZIF-67/C-600 revealed the presence of some meso- and macropores. Since the particle size of the ZIF-67 precursor was only $44 \mathrm{~nm}$, the macropores are not derived from the heat treatment of ZIF-67. On the other hand, they may come from the space between the pyrolyzed precursor and BP 2000. The 

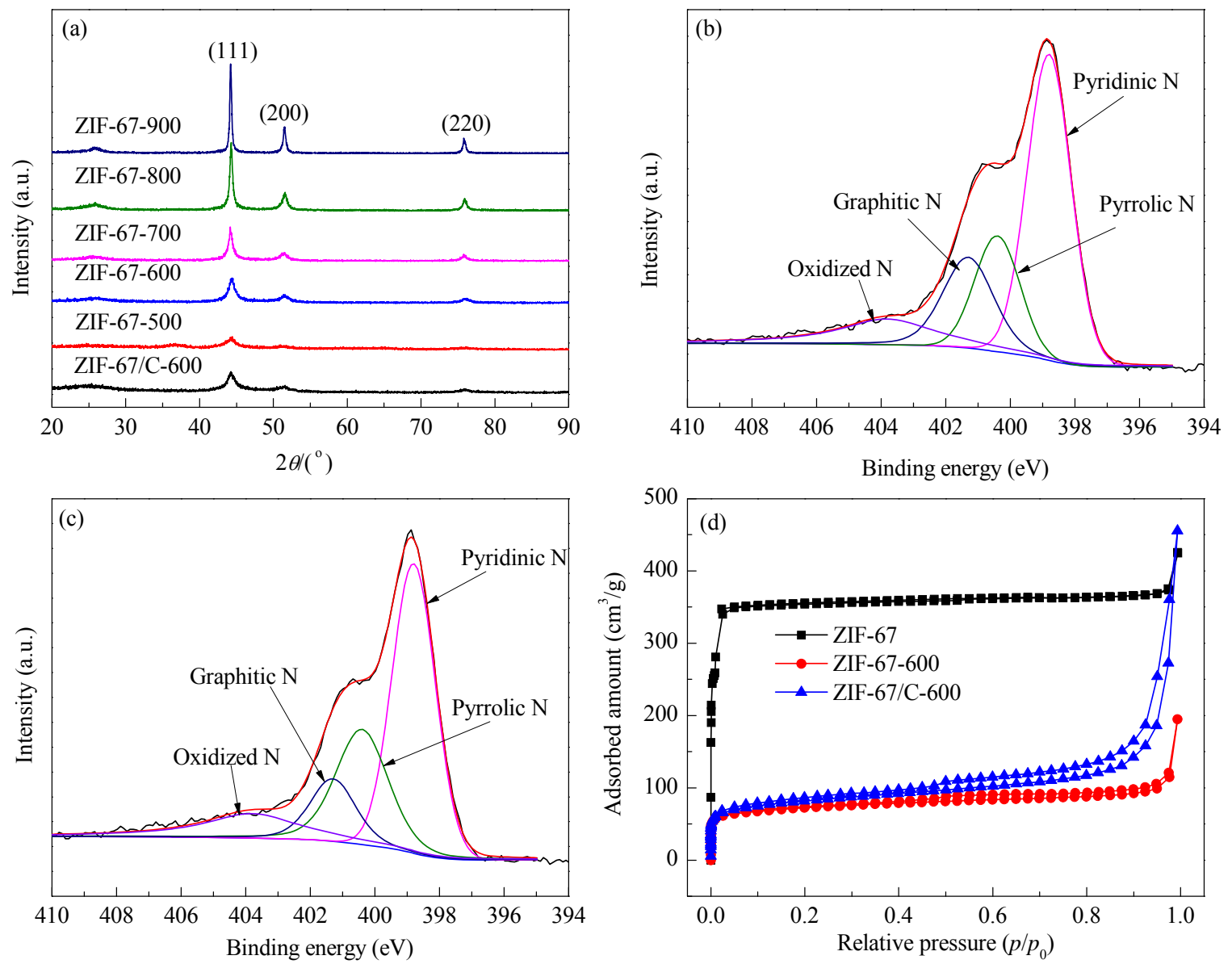

Fig. 2. XRD patterns of ZIF-67/C-600 and ZIF-67-Tc (a); N 1s XPS spectrum of ZIF-67-600 (b) and ZIF-67/C-600 (c); $\mathrm{N}_{2}$ adsorption-desorption isotherms of ZIF-67, ZIF-67-600 and ZIF-67/C-600 (d).

surface area of ZIF-67/C-600 was $296 \mathrm{~m}^{2} / \mathrm{g}$, which was a little higher than ZIF-67-600 (268 $\left.\mathrm{m}^{2} / \mathrm{g}\right)$. The relatively large surface area contributed to the enhanced ORR performance of ZIF-67/C-600 as compared to that of ZIF-67-600.

To evaluate the electrochemical performance of ZIF-67-Tc and ZIF-67/C-600 for the ORR, CV and RDE experiments were conducted in $0.1 \mathrm{~mol} / \mathrm{L} \mathrm{KOH}$ aqueous solution. Fig. 3(a) shows the RDE polarization curves of the electrocatalysts prepared by the pyrolysis of the ZIF-67 precursor at 500 to $900{ }^{\circ} \mathrm{C}$ and ZIF-67/C at $600^{\circ} \mathrm{C}$. With the increase of pyrolysis temperature, the electrochemical performance increased from 500 to $600{ }^{\circ} \mathrm{C}$ in terms of the onset potential and half-wave potential for the ORR. ZIF-67-600 exhibited the highest performance among the ZIF-67-Tc electrocatalysts with a ORR half-wave potential of $0.833 \mathrm{~V}$ and limiting current density of $5 \mathrm{~mA} / \mathrm{cm}^{2}$. This may be due to the dominant presence of pyridinic-N in ZIF-67-600 for

Table 1

Content of nitrogen species and BET areas of ZIF-67-600 and ZIF-67/C-600.

\begin{tabular}{lcccccc}
\hline \multirow{2}{*}{ Sample } & $\mathrm{N}$ & \multicolumn{4}{c}{ Nitrogen species (\%) } & \multirow{2}{*}{\begin{tabular}{c} 
ABET \\
\cline { 3 - 6 }
\end{tabular}} \\
\cline { 3 - 6 } & (at\%) & Pyridinic & Pyrrolic & Graphitic & Oxidized & $\left(\mathrm{m}^{2} / \mathrm{g}\right)$ \\
\hline ZIF-67-600 & 5.80 & 49.2 & 19.0 & 18.6 & 13.2 & 268 \\
ZIF-67/C-600 & 5.58 & 48.1 & 26.1 & 12.3 & 13.4 & 296 \\
\hline
\end{tabular}

the promotion of the four-electron process in ORR, which gave a better performance than the N/Co-doped PCP electrocatalyst of Hou et al. [32] who directly pyrolyzed the as-synthesized $500 \mathrm{~nm}$ ZIF-67. This may be because the smaller ZIF-67 can supply more active and easily accessible sites and thus promote a faster mass and electron transfer. Further increase of the pyrolysis temperature led to a decline of ORR performance. The different heat treatment temperatures can result in a different pore structure and different relative contents of carbon, nitrogen and metal species on the electrocatalysts, which affect the ORR performance of the electrocatalysts. When loaded on BP 2000, the resulting ZIF-67/C-600 showed an even better electrocatalytic performance than ZIF-67-600 with the ORR onset and half-wave potential as high as 0.982 and $0.842 \mathrm{~V}$, respectively, relative to RHE. The dominant pyridinic-N and slightly increased pyrrolic- $\mathrm{N}$ were the active sites for the four-electron process in ORR. In addition, the relatively large surface area contributed to the enhanced ORR performance of ZIF-67/C-600 compared to ZIF-67-600. Furthermore, the addition of BP 2000 improved the dispersion and electroconductivity of ZIF-67/C-600, which would also enhance the ORR performance of ZIF-67/C-600.

The loading of ZIF-67/C-600 on RDE was optimized as shown in Fig. 3(b). The optimal loading was reached at 1 

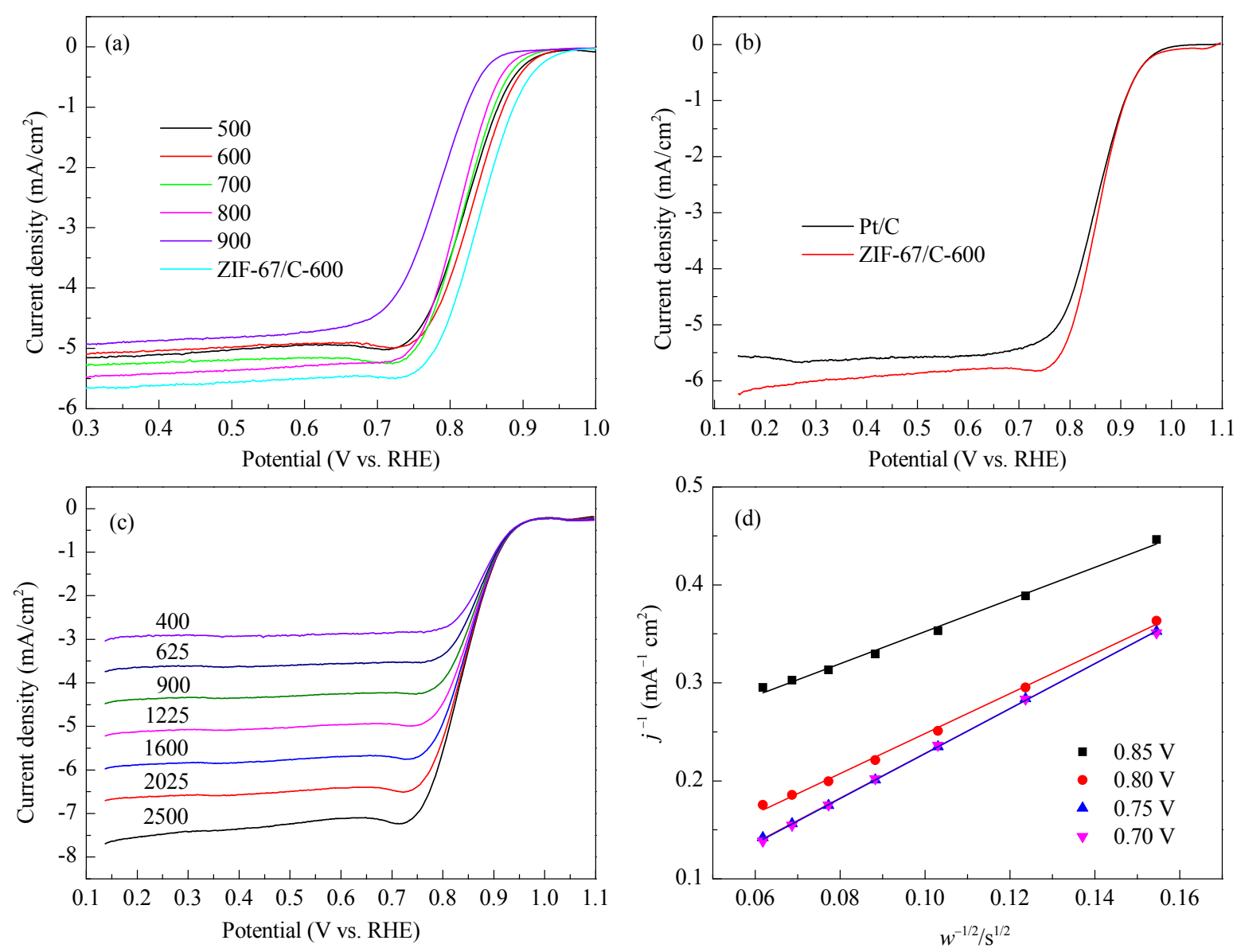

Fig. 3. (a) RDE polarization curves of ZIF- 67 heat-treated at $500-900{ }^{\circ} \mathrm{C}$ and ZIF- $67 / \mathrm{C}-600$. The catalysts loading was $0.4 \mathrm{mg} / \mathrm{cm}^{2}$, the rotational speed was $1600 \mathrm{r} / \mathrm{min}$. (b) RDE polarization curves of ZIF-67/C-600 (1.0 mg/cm²) and Pt/C (20 wt\%, Johnson Matthey, $\left.20 \mu \mathrm{ggt}_{\mathrm{Pt}} / \mathrm{cm}^{2}\right)$, the rotational speed was $1600 \mathrm{r} / \mathrm{min}$. (c) RDE polarization curves of ZIF-67/C-600 in $\mathrm{O}_{2}$-saturated $0.1 \mathrm{~mol} / \mathrm{L} \mathrm{KOH}$ with various rotation rates at a scan rate of 5 $\mathrm{mV} / \mathrm{s}$. (d) Koutecky-Levich plots of ZIF-67/C-600 at different potentials derived from the ORR polarization curves in (c).

$\mathrm{mg} / \mathrm{cm}^{2}(1.017 \mathrm{~V}$ for onset and $0.857 \mathrm{~V}$ for half wave potential vs. RHE). It is worth pointing out that the half-wave potential was even superior to that of commercial Pt/C $(1.017 \mathrm{~V}$ for onset and $0.853 \mathrm{~V}$ for half wave potential vs. RHE). Fig. 3(c) shows the ORR polarization curve of ZIF-67/C-600 at different rotating rates. The diffusion limited current density of ZIF-67/C-600 became larger with increased rotation rate. As shown in Fig. 3(d), the corresponding Koutecky-Levich (K-L) plots showed good linearity and were nearly parallel at different potentials, which revealed first ordered reaction kinetics with respect to the concentration of dissolved $\mathrm{O}_{2}$.

Fig. 4(a) illustrates the electron transfer number $(n)$ in the ORR process. Fig. 4(b) shows the hydrogen peroxide yield $\left(\% \mathrm{H}_{2} \mathrm{O}_{2}\right)$ calculated from the RRDE results for ZIF-67/C-600 and commercial Pt/C in alkaline solution. A value of $n$ of 4 represents $100 \%$ of water formation, while a value of $n$ of 2 represents $100 \%$ peroxide formation. The $n$ number for both electrocatalysts was between 3.9 and 4.0, indicating that the ORR on both ZIF-67/C-600 and Pt/C was dominated by a 4e process and $\% \mathrm{H}_{2} \mathrm{O}_{2}$ (or $\% \mathrm{HO}_{2}-$ ) was below $1 \%$ for $\mathrm{Pt} / \mathrm{C}$ and $3.5 \%$ for ZIF-67/C-600, respectively. This confirmed that the 4e reduction to water dominated for both electrocatalysts in alkaline medium.
During the accelerated stability test (AST), CV curves and ORR polarization curves were collected in aqueous $\mathrm{KOH}$ solution at specific cycles to track the degradation of ZIF-67/C-600 and commercial Pt/C. Fig. 4(c) shows the current density degradation of ZIF-67/C-600 and commercial Pt/C after being cycled between 0.497 and $1.097 \mathrm{~V}$ for a total number of 2000 cycles in $\mathrm{O}_{2}$ saturated $\mathrm{KOH}(0.1 \mathrm{~mol} / \mathrm{L})$ with a scan rate of 100 $\mathrm{mV} / \mathrm{s}$. It is clear that $96 \%$ of the initial current density of ZIF-67/C-600 toward ORR was maintained, which is much better than that of the commercial Pt/C (59\%). The deactivation of $\mathrm{Pt} / \mathrm{C}$ was mainly due to the dissolution of Pt nanoparticles active sites at high potentials. This was not the case for NPME. Also, the chemically and mechanically stable BP 2000 contributed to the stability improvement [33]. More importantly, Fig. 4(d) showed that ZIF-67/C-600 also exhibited better methanol tolerance than commercial Pt/C. A sharp increase in the current density was observed for commercial $\mathrm{Pt} / \mathrm{C}$ after the introduction of $10 \mathrm{vol} \%$ methanol into the alkaline solution, while the ZIF-67/C-600 was only slightly affected.

\section{Conclusions}

Smaller Co-based ZIF-67 nanoparticles were synthesized for 

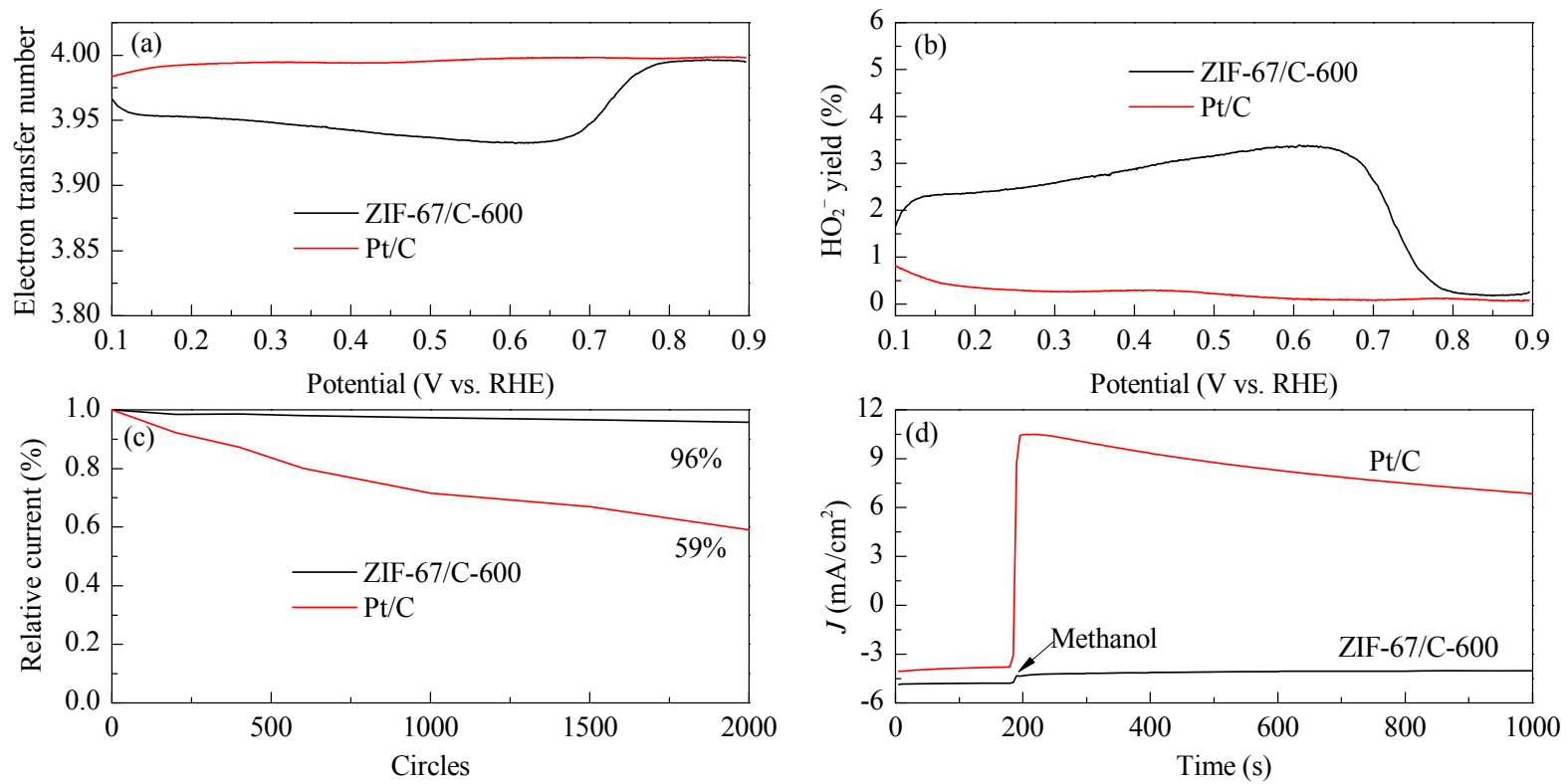

Fig. 4. Electron-transfer number (a) and $\% \mathrm{H}_{2} \mathrm{O}_{2}$ (b) of ZIF-67/C-600 and commercial $20 \% \mathrm{Pt} / \mathrm{C}$ in the ORR process; Stability of ZIF-67/C-600 and JM $20 \% \mathrm{Pt} / \mathrm{C}$ in $\mathrm{O}_{2}$-saturated $0.1 \mathrm{~mol} / \mathrm{L} \mathrm{KOH} \mathrm{(c);} \mathrm{Chronoamperometric} \mathrm{response} \mathrm{of} \mathrm{ZIF-67/C-600} \mathrm{and} \mathrm{JM} \mathrm{20 \%} \mathrm{Pt/C} \mathrm{at} 1600 \mathrm{r} / \mathrm{min}$ (d). The arrow indicates the introduction of $10 \mathrm{vol} \%$ methanol.

the first time. A NPME was made by the pyrolysis of ZIF-67 with and without a BP 2000 support. The ZIF-67/C-600 electrocatalyst exhibited high ORR performance in alkaline solution, and it was superior to the commercial Pt/C catalyst in terms of the ORR half-wave potential. ZIF-67/C-600 also has a better long term stability and resistance to methanol crossover. The high electrochemical performance was attributed to the abundant pyridinic nitrogen species and the high surface area of ZIF-67/C-600. These advantages make the ZIF-67/C-600 catalyst a possible candidate for substituting the conventional Pt-based electrocatalysts in alkaline media.

\section{References}

[1] D. Zhao, J. L. Shui, C. Chen, X. Q. Chen, B. M. Reprogle, D. P. Wang, D. J. Liu, Chem. Sci., 2012, 3, 3200-3205.

[2] J. S. Li, Y. Y. Chen, Y. J. Tang, S. L. Li, H. Q. Dong, K. Li, M. Han, Y. Q. Lan, J. C. Bao, Z. H. Dai, J. Mater. Chem. A, 2014, 2, 6316-6319.

[3] H. A. Gasteiger, S. S. Kocha, B. Sompalli, F. T. Wagner, Appl. Catal. B, 2005, 56, 9-35.

[4] J. B. Wu, H. Yang, Acc. Chem. Res., 2013, 46, 1848-1857.

[5] W. F. Si, H. Q. Li, Y. Jie, S. S. Li, Y. Xie, J. Li, Y. Lv, Y. Liu, Y. H. Xin, H. Xu, Y. J. Song, Chin. J. Catal., 2012, 33, 1601-1607.

[6] P. Zhang, F. Sun, Z. H. Xiang, Z. G. Shen, J. Yunb, D. P. Cao, Energy Environ. Sci., 2014, 7, 442-450.

[7] L. J. Zhang, Z. X. Su, F. L. Jiang, L. L. Yang, J. J. Qian, Y. F. Zhou, W. M. Li, M. C. Hong, Nanoscale, 2014, 6, 6590-6602.

[8] J. Zhang, S. H. Tang, L. Y. Liao, W. F. Yu, Chin. J. Catal., 2013, 34, 1051-1065.

[9] F. Afsahi, S. Kaliaguine, J. Mater. Chem. A, 2014, 2, 12270-12279.

[10] M. P. Suh, H. J. Park, T. K. Prasad, D. W. Lim, Chem. Rev., 2012, 112, 782-835.

[11] L. J. Murray, M. Dinca, J. R. Long, Chem. Soc. Rev., 2009, 38, 1294-1314.

[12] G. Ferey, C. Serre, T. Devic, G. Maurin, H. Jobic, P. L. Llewellyn, G. De
Weireld, A. Vimont, M. Daturi, J. S. Chang, Chem. Soc. Rev., 2011, $40,550-562$.

[13] J. R. Li, J. Sculley, H. C. Zhou, Chem. Rev., 2012, 112, 869-932.

[14] J. R. Li, R. J. Kuppler, H. C. Zhou, Chem. Soc. Rev., 2009, 38, 1477-1504.

[15] J. Y. Lee, O. K. Farha, J. Roberts, K. A. Scheidt, S. B. T. Nguyen, J. T. Hupp, Chem. Soc. Rev., 2009, 38, 1450-1459.

[16] K. E. de Krafft, Z. G. Xie, G. H. Cao, S. Tran, L. Q. Ma, O. Z. Zhou, W. B. Lin, Angew. Chem. Int. Ed., 2009, 48, 9901-9904.

[17] D. M. Liu, R. C. Huxford, W. B. Lin, Angew. Chem. Int. Ed., 2011, 50, 3696-3700.

[18] L. E. Kreno, K. Leong, O. K. Farha, M. Allendorf, R. P. Van Duyne, J. T. Hupp, Chem. Rev., 2012, 112, 1105-1125.

[19] M. Kurmoo, Chem. Soc. Rev., 2009, 38, 1353-1379.

[20] W. Xia, J. H. Zhu, W. H. Guo, L. An, D. G. Xia, R. Q. Zou, J. Mater. Chem. A, 2014, 2, 11606-11613.

[21] Q. Li, P. Xu, W. Gao, S. G. Ma, G. Q. Zhang, R. G. Cao, J. Cho, H. L. Wang, G. Wu, Adv. Mater., 2014, 16, 1378-1386.

[22] W. Zhang, Z. Y. Wu, H. L. Jiang, S. H. Yu, J. Am. Chem. Soc., 2014, $136,14385-14388$.

[23] X. J. Wang, J. W. Zhou, H. Fu, W. Li, X. X. Fan, G. B. Xin, J. Zheng, X. G. Li, J. Mater. Chem. A, 2014, 2, 14064-14070.

[24] H. Hu, L. Han, M. Z. Yu, Z. Y. Wang, X. W. Lou, Energy Environ. Sci., 2016, 9, 107-111.

[25] B. L. Chen, R. Li, G. P. Ma, X. L. Gou, Y. Q. Zhu, Y. D. Xia, Nanoscale, 2015, 7, 20674-20684.

[26] A. Aijaz, J. Masa, C. Rçsler, W. Xia, P. Weide, A. J. R. Botz, R. A. Fischer, W. Schuhmann, M. Muhler, Angew. Chem. Int. Ed., 2016, 55, 4087-4091.

[27] Y. Y. Liang, Y. G. Li, H. L. Wang, J. G. Zhou, J. Wang, T. Regier, H. J. Dai, Nat. Mater., 2011, 10, 780-786.

[28] G. Wu, K. L. More, C. M. Johnston, P. Zelenay, Science, 2011, 332, 443-447.

[29] J. R. Pels, F. Kapteijn, J. A. Moulijn, Q. Zhu, K. M. Thomas, Carbon, 1995, 33, 1641-1653.

[30] Z. Y. Sun, J. Masa, P. Weide, S. M. Fairclough, A. W. Robertson, P. 


\title{
Graphical Abstract
}

Chin. J. Catal., 2016, 37: 1127-1133 doi: 10.1016/S1872-2067(15)61104-4

\section{A high performance non-noble metal electrocatalyst for the oxygen reduction reaction derived from a metal organic framework}

Yangzhi Bai, Baolian Yi, Jia Li, Shangfeng Jiang, Hongjie Zhang,

Zhigang Shao*, Yujiang Song*

Dalian Institute of Chemical Physics, Chinese Academy of Sciences;

University of Chinese Academy of Sciences;

Dalian University of Technology

We reported the synthesis of a NPME by heat-treating cobalt-based metal organic frameworks (ZIF-67, with a small size of $44 \mathrm{~nm}$ ) from $500-900{ }^{\circ} \mathrm{C}$. The electrocatalyst pyrolyzed at $600{ }^{\circ} \mathrm{C}$ showed the best performance and the performance was enhanced when it was supported on BP 2000.

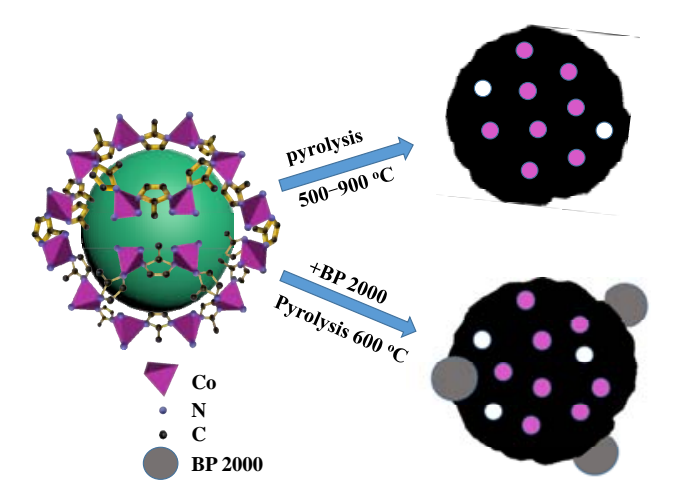

Ebbinghans, J. H. Warner, S. C. E. Tsang, M. Muhler, W. Schuhmann, J. Mater. Chem. A, 2015, 3, 15444-15450.

[31] F. Jaouen, S. Marcotte, J. P. Dodelet, G. Lindbergh, J. Phys. Chem. B, 2003, 107, 1376-1386.
[32] Y. Hou, Z. H. Wen, S. M. Cui, S. Q. Ci, S. Mao, J. H. Chen, Adv. Funct. Mater., 2015, 25, 872-882.

[33] Y. Xie, H. Q. Li, C. Z. Tang, S. S. Li, J. Li, Y. Lv, X. M. Wei, Y. J. Song, J. Mater. Chem. A, 2014, 2, 1631-1635.

\section{以金属有机骨架为前驱体的高活性氧还原非贵金属催化剂制备}

\author{
白杨芝 ${ }^{\mathrm{a}, \mathrm{b}}$, 衣宝廉 ${ }^{\mathrm{a}}$, 李 佳 $^{\mathrm{c}}$, 蒋尚峰 ${ }^{\mathrm{a}}$, 张洪杰 ${ }^{\mathrm{a}}$, 邵志刚, ${ }^{\mathrm{a},}$ ，宋玉江, ${ }^{\mathrm{c}, \#}$ \\ ${ }^{\mathrm{a}}$ 中国科学院大连化学物理研究所, 洁净能源国家实验室(筹), 辽宁大连 116023 \\ ${ }^{\mathrm{b}}$ 中国科学院大学, 北京 100049 \\ ${ }^{c}$ 大连理工大学化工系, 精细化工国家重点实验室, 辽宁大连 116024
}

摘要: 燃料电池具有能量转化效率高、功率密度高、低温操作、无污染等优点, 因而在电动汽车动力源、移动式电源及分 散电站等领域具有广阔的应用前景. $\mathrm{Pt} / \mathrm{C}$ 催化剂是目前使用最广泛的燃料电池阴极氧还原反应 (ORR) 的催化剂, 然而其 有限的储量、较低的稳定性、易 CO 中毒等缺点限制了燃料电池的大规模商业化, 因此研制高活性和稳定性的非贵金属催 化剂以代替 $\mathrm{Pt} / \mathrm{C}$ 催化剂显得至关重要. 金属有机骨架 $(\mathrm{MOFs})$ 是由金属阳离子和有机配体配位而成的结构可调的空间三 维材料, 其作为前驱体制备非贵金属 ORR 催化剂具有独特的优势: (1) MOFs 的三维晶体结构可以提供高的活性位点密 度; (2) 有机配体可以在热解的过程中转化为碳支撑体, 使得活性金属物质和碳支撑体可以同时生成; (3) 可以调节形成 MOFs 的金属离子和有机配体来设计一定特性的 MOFs 结构, 从而制备结构和功能可调的催化剂; (4) MOFs 具有可调控 的孔径尺寸及可修饰的孔道表面, 其较大的比表面积和不同孔隙分布有利于吸附反应物氧气分子, 而且可以得到不同元素 和金属掺杂的多孔碳材料. 因此, 本文选择 MOF 材料 ZIF-67 作为前驱体, 通过在 500-900 ${ }^{\circ} \mathrm{C}$ 高温热处理制备了非贵金属 ORR 催化剂, 在 $0.1 \mathrm{~mol} / \mathrm{L} \mathrm{KOH}$ 溶液中进行电化学测试, 发现其中 $600{ }^{\circ} \mathrm{C}$ 热处理得到的催化剂的活性较好. 为了进一步 提高催化剂的导电性和分散性, 对该催化剂进行了 BP 2000 碳载处理. 电化学测试发现, 该催化剂的 ORR 活性进一步提 高: 当载量为 $1.0 \mathrm{mg} / \mathrm{cm}^{2}$ 时, 其 ORR 起始电位和半波电位分别达 1.017 和 $0.857 \mathrm{~V}$ (vs. RHE), 与商业化 Pt/C $\left(20 \mu \mathrm{g}_{\mathrm{P}} / \mathrm{cm}^{2}\right)$ 的性能相近. 透射电镜结果表明, 制备的催化剂为单质 Co 粒子镶嵌的 N 掺杂的多孔碳材料, 其中 Co 粒子的粒径为 $10 \mathrm{~nm}$ 左右, 其存在可由 $X$ 射线衍射测试得以确认. $X$ 射线光电子能谱表征显示, 碳载得到的催化剂中 $N$ 原子主要以吡啶型存 在, 后者可能起到一定的 ORR 活性位点作用, 且其比表面积为 $296 \mathrm{~m}^{2} / \mathrm{g}$, 高于未碳载的 $268 \mathrm{~m}^{2} / \mathrm{g}$, 也有利于提高其电化学 活性. 结果还显示, 与商业化 $\mathrm{Pt} / \mathrm{C}$ 相比, 碳载催化剂具有更好的抗甲醇性和稳定性.

关键词: 燃料电池; 氧还原反应; 非贵金属催化剂; 金属有机骨架; 碱性电解液

收稿日期: 2016-03-15. 接受日期: 2016-04-12. 出版日期: 2016-07-05.

*通讯联系人. 电话: (0411)84379153; 传真: (0411)84379153; 电子信箱: zhgshao@dicp.ac.cn

\#通讯联系人. 电子信箱: yjsong@dlut.edu.cn

基金来源：国家重点基础研究发展计划 (973 计划, 2015CB932304); 国家自然科学基金 (21436003).

本文的英文电子版由Elsevier出版社在ScienceDirect上出版(http://www.sciencedirect.com/science/journal/18722067). 